\title{
THE EUROPEAN ECONOMIC COMMUNITY AND ECONOMIC ASSOCIATION.
}

I am grateful to the Afrika-Seminaar of the Potchefstroom University for inviting me to give a talk on the European Economic Community and the Association of the Overseas Countries and Territories.

For practical reasons I thought it best to divide my lecture in two parts, the first dealing with the historical background of the Treaty of Rome, its provisions and the construction of the European Economic Community. The second part will enable me amongst others to envisage the political and economic development of Europe to be expected from the implementation of this spectacular arrangement concluded by the so-called Six, i.e. Belgium,
France, Germany, Italy, Luxemburg and the Netherlands.

I will say a few words on the Free Trade Area, or the European Economic Association as it is formally baptized, a necessary and logical component of what has been set into motion by the creation of the European Economic Community.

The idea of a European Community is not new. During the centuries after the decline of the Holy Roman Empire in the Middle Ages there has always been a hankering after the re-establishment of European unity. Europe, unfortunately, needed the experience of two devastating wars, before the idea of a Union of the European countries 
ceased to remain a utopian illusion. These sad experiences, however, would not have been sufficient to force the governments and peoples of a number of European countries to establish closer ties, had it not been for the fact that the reconstruction of their economies after the second world war proved to be impossible without a certain amount of co-operation and co-ordination of their economic policies.

The generous offer of the United States known as Marshall aid is to a large extent responsible for the economic co-operation, characteristic of Europe today.

An impulse to the co-operative development in Europe was undoubtedly caused by the implementation of the decision of the exile governments of Belgium, Luxemburg and the Netherlands in 1944 to conclude a Treaty providing for the establishment of an economic union between these three countries, the so-called Benelux. I do not think that, at the moment, the governments concerned were aware of the fact that this step would prove to be the very beginning of what was to become the European Economic Community. Although the creation of Benelux is a thing in itself, the difficulties the three countries experienced while trying to implement the idea agreed upon under the stress of the war conditions, served as an instructive example to later developments.

The conditions attached by the Government of the United States to the Marshall aid caused the establishment of the Organization for European Economic Co-operation. This organiza- tion has played a very constructive role not only with regard to making an efficient use of the milliards in aid of the reconstruction of the economy of the European countries, but particularly as regards the establishment of a closer economic co-operation between the countries concerned and the liberalization of commerce between the member countries, etc. The European payments Union, a subsidiary of the O.E.E.C., has provided the member countries with clearing and credit facilities which have contributed considerably to the expansion of trade in post-war Europe. But as the provisions of the Treaty establishing the O.E.E.C. required unanimity of all the members on the proposals being put forward, there was a certain limit beyond which the organization proved to be powerless.

It was the then French Minister of Foreign Affairs, Mr. Schumann, who unexpectedly on the 9 th of May 1950 launched the idea of the establishment of a European Coal and Steel community. This bold plan made provision for the establishment of a common market for coal, steel, ore and scrapiron and for a High Authority equipped with supranational powers. It implied the transfer of a large amount of national sovereignty by the member countries to the High Authority on matters affecting amongst others production, distribution, consumption, transport, prices, competition and cartelization. Parliamentary control on the activities of the High Authority had to be vested in the Coal and Steel parliament consisting of representatives chosen by national parliaments of the 
member countries. Moreover a Court of Justice had to be set up in order to ensure the respect of the law concerning the interpretation and the application of the provisions of the Treaty.

The appeal of Mr. Schumann got an immediate favourable response of Germany, Italy and the Benelux-countries. The United Kingdom, however, notwithstanding the pressure brought to bear upon its Government decided not to take part in the Community as envisaged. This refusal which caused the Scandinavian countries to stay out. did not prevent the countries I mentioned to negotiate on the Schumann plan. Finally in 1951 the Treaty establishing the European Coal and Steel community was signed and duly ratified before August, 1952. On the 10th of February, 1955 the Common Market for coal, ore and scrap-iron was officially established and on the 10th of April the Common Market for steel was called into being.

In this connection I wish to say that the attitude of the United Kingdom is understandable. Although at the time the continental countries were prepared to make maximal concessions to get Great Britain in, the British Government, used to a pragmatic approach to national and international problems. showed an unsurmountable reluctance to abandon sovereignty to an organization that had still to prove its workability and efficiency. The United Kingdom therefore was not prepared to take what looked like a leap into the dark.

After a few years when the Coal and Steel community had proved its viability, a Treaty was signed between the High Authority and the United Kingdom, resulting in association of Great Britain with the European Coal and Steel Community.

The first years of the integration history of Europe were marked by the difference of opinion between two groups. One group believed that the gradual expansion of sectional integration would ultimately result in an overall integration of the economies of the six countries. The other group doubted whether such a gradual development could be expected, and advocated an approach to the realization of overall integration at once. As at the time the integration idea was strongly influenced by political factors, in particular the French suspicions concerning Germany and the French efforts to prevent an eventual resurrection of the German danger, France pinned its faith on the establishment of a European Defence Community and a European Political Community. Both plans foundered as a result of strong opposition in France itself. Perhaps we should thank France for shrinking from the consequences of its own schemes. Although the rejection of the European Defence Community by the French Parliament initially had a paralysing effect on the construction of the European edifice, it allowed the European statesmen to look for a new approach to the extension of European integration. The experiences with the European Coal and Steel community had already shown that those who believed that an overall intergration of the economies of the member countries 
could hardly be attained by the way of sectional integration, were right.

The failure of the European Defence Community and the Political Community, both of a political nature, on the other hand showed that there was no chance whatsoever to realize the political idea of a united Europe as long as the economies of the participating countries did not become merged.

If a wide common market could be realized not only by eliminating all customs and other barriers in mutual trade between the Six but also by establishing a common external tariff and means of a common economic policy to be laid down by common institutions equipped with the necessary powers, an important step had been set on the road to a merging of the economies of the member countries.

This train of thought induced Dr. Spaak and Dr. Beyen respectively Belgian Prime Minister and Netherlands Minister of Foreign Affairs to persuade the governments of France, Germany, Italy and Luxemburg of the necessity of another effort, aimed at the realization of an overall economic integration of the six countries.

In July 1955 a conference was called at Messina in Sicily, where the countries concerned decided to concentrate on economic integration. After long and often difficult negotiations, the endeavours were crowned with success and the Treaty of Rome was signed in $\mathbf{1 9 5 7}$ by the six countries mentioned above: Belgium, France, Germany, Italy. Luxemburg and the Netherlands.
The Treaty, which has meanwhile been ratified and has entered into force, does not disguise that the realisation of its provisions is only a means to arrive at the political unity of the European nations. The preamble preceding the text of the Treaty states this in so many words and calls on the other European countries to join the Community.

So much as far as the historical background is concerned. I come now to the Treaty itself and its main contents. First and foremost it should be kept in mind that the Treaty establishing the European Economic Community is not identical with the European Common Market. The European Common Market is only part of the Treaty, though a very essential one.

The first part of the Treaty deals with the guiding principles. It is said that the undertaking aims at fostering throughout the Community the harmonious development of economic activities, a continuous and balanced expansion, an increased stability, an accelerated raising of the standard of living and closer relations between the countries taking part in the Community. The means to be used in order to realize this purpose are the abolishment of customs barriers and existing quantitative restrictions impeding the expansion of trade between the member countries; the establishment of a common outer tariff and the pursuance of a common trade policy towards third countries; the elimination of the obstacles to the free movement of persons, services and capital; the setting up of a common agricultural policy and of a common 
transport policy; the establishment of rules concerning competition; the co-ordination of the economic policy of the participating countries and the application of procedures to prevent a disequilibrium of the balance of payments of the countries concerned, the creation of a European Social Fund to facilitate employment and to promote the geographical and professional mobility of the workers, the establishment of a European Investment Bank and the Association of the Overseas Territories.

The Treaty makes provision for the necessary institutions which are responsible for the proper functioning of the Community. Otherwise than the High Authority of the European Coal and Steel Community vested with supranational powers, the European Commission has, as a rule, not the authority "sui generis" to impose its will on the governments of the participating countries. Nevertheless the European Commission functions independently of the Council of Ministers. Its task is to ensure the application of the provisions of the Treaty and to formulate recommendations or opinions on matters which are subject to the Treaty. The Commission participates in the prepa. ration of acts of the Council of Ministers and the Assembly and exercises the competence conferred on it by the Council for the implementation of the rules laid down by the latter. It has nine members, chosen for their general competence and of indisputable independence. They are appointed by the governments of the member states in common agreement for a period of four years. Their term of office is renewable. The European Commission has to publish a general report on the activities of the Community, not later than one month before the opening of the session of the Assembly on the third Tuesday of October.

The Council of Ministers has six members, each country delegating one member. This institution ensures the co-ordination of the general economic policies of the participating countries and in this regard disposes of a decisive power. Usually the conclusions of the Council are reached by majority vote of its members. With the exception of the first and second stage of the transition period, there are only a few instances where the Treaty requires unanimous decisions.

The Treaty mentions three different types of decisions, by the Council, i.e. by ordinary majority or by qualified majority. In the latter case the votes are weighed; Germany, France and Italy registering 4 votes each; Belgium and the Netherlands two, and Luxemburg one. If a proposal has been tabled by the European Commission, a minimum of 12 votes should be cast in favour of it. If not, the 12 votes should include the votes of four of the six member countries. On the other hand a proposal of the European Commission can only be amended by unanimous vote of the Council.

The European Commission together with the Council of Ministers are the responsible policy makers of the Community. Although it is impossible to elaborate on their future policy, it has to be in conformity with the general 
principles of the Treaty. Apart from the general principles already mentioned, they all stress the continued validity and respect for all previous rights and obligations and the need for promoting commercial exchanges between the member states and third countries. They aim at contributing to the progressive abolition of restrictions on international commercial exchanges, the lowering of trade barriers and the harmonious development of world trade.

In this context I like to stress the open character of the Community. The Treaty specifies that the Community is open to all European countries wishing to participate and willing to accept its obligations together with its rights. The Treaty furthermore authorises the Community to conclude with a third country or international organizations agreements providing for an association embodying reciprocal rights and obligations, joint actions and special procedures.

The European Assembly exercises control over the activities of the Community. Its members are elected by the national parliaments of the participating countries. The Assembly discusses the annual report drawn up by the European Commission. A motion of censure has to be approved by twothirds of the cast votes in which case the Commission collectively resigns.

The Assembly, which is at the same time the controlling parliamentary institution envisaged by the European Economic Community, the European Atomic Energy Community as well as the European Coal and Steel Community, is moreover charged with the drawing up of the proposals providing for direct universal suffrage in accordance with a uniform procedure in all member states. 'The Council of Ministers has to agree unanimously on these proposals.

I had the opportunity to watch for a couple of years the proceedings of the European Coal and Steel parliament. and $I$ was very much impressed by the way the Assembly exercised its task. Although vested with a minimum of authority, the Assembly immediately showed its earnest desire to make the utmost of it. After a short time the Assembly had organised itself into a full-fledged parliament making its influence more and more felt on the High Authority. To the dismay of the framers of the Treaty, the High Authority proved to be too readily disposed to meet as far as possible the interference of the Assembly with its activities. There was a continuous tendency of the Assembly to interpret as amply as possible the authority assigned to it by the Treaty.

Another peculiar development next to the constitution of parliamentary committees was the formation of political groups. The by-laws governing the procedure of the Assembly even allow part of the annual budget of this institution to be used for financing the organizational structure of the different political groups. It became a custom that criticism was levelled against the High Authority by a member of parliament stating that he was authorized to express the view of the Christian Democratic, of the Social democratic or the Liberal political group of the 
House concerning a certain matter. As far as I know there was never a division of the House along national lines.

As the European Assembly is an enlargement of the Coal and Steel parliament, it will undoubtedy carry on in the same way.

The Court of Justice, the fourth institution, has to ensure the observance of law and justice in the interpretation and application of the Treaty, and is composed of seven judges, assisted by two solicitors-general and by a clerk. The judges and solicitors-general are chosen by the unanimous decision of the governments concerned. The Court is at the same time the juridical organ of the European Coal and Steel Community and the European Atomic Energy Community.

The Council of Ministers and/or the European Commission in a number of cases mentioned in the Treaty have to ask the advice of the Economic and Social Committee. In this Committee producers, artisans, the liberal professions and the general interest are represented. Like the Assembly and the Court of Justice, the Economic and Social Committee is a common organ performing at the same time the functions assigned to this institution in the treaties establishing the European Coal and Steel Community and the European Atomic Energy Community.

It is evident that a more or less revolutionary construction like the European Economic Community can only be realized if the national economies which are merged into it are given some time to adapt themselves to the new situation. Therefore the fusion of the different economies is spread out over a period of twelve years divided into three stages of four years each.

As the duration of the first stage can under circumstances be prolonged for three years, the transition period can last fifteen years at the most. This maximum period applies equally to the establishment of the common tariff as well as to the elimination of the internal trade and tariff barriers, to the free circulation of capital and to the free movement of labour. This knowledge is a powerful incentive for the responsible authorities and for those whose interest will be affected to take the necessary measures to adapt their economies and interests to the new situation. During the transition period the tariff barriers now existing between the member countries will gradually be eliminated, according to fixed scales. The same applies to the quota systems.

The Treaty moreover makes provision for the establishment of a common external tariff which will progressively replace the existing tariffs of the member states. The new common tariff will be fully applied at the end of the transition period.

For certain groups of products the Treaty provides a maximum import duty which the common tariff is not allowed to exceed. These ceilings are: $3 \%$ for raw materials; $10 \%$ for half products; $15 \%$ for inorganic chemical products and $25 \%$ for organic chemical products. However, for a certain number of products the duty could only be established as a result of negotiations. For some products negotiations between member countries have not yet been 
complete. If no agreement is reached, they will be determined by the Council of Ministers on the proposal of the European Commission. The national tariffs will gradually be brought into line with the common tariff by means of three successive adjustments which will take place at the end of three stages into which the transition period has been divided. The rhythm of adjustment is as follows. At the end of the first stage, that is at the earliest 4 years after the entry into force of the Treaty, the common tariff will apply to all those items which do not differ from the common tariff by more than $15 \%$ either more or less. For all other items the gap between the national tariff and the common tariff will be reduced by $30 \%$. At the end of the second 4-years stage a new adjustment of $30 \%$ is to be made, and at the end of the transition period the common tariff will be fully applied. Although the general incidence of the new common tariff is in conformity with the provisions of the GATT Treaty, it must be admitted that the level of the common tariff with regard to certain specific items will be higher than those now applied in some participating countries. This applies in particular to the Benelux tariff. On the other hand the level of the common tariff will be lower for those items than the actual tariff in France and Italy. I wish, however, to point out that those countries who fear that their interests might be affected by tariff increases on certain specific items should take into account that the common tariff will only very gradually be put into effect over a period of 12 to $\mathbf{1 5}$ years and the first initial changes will only be made after 4 at the earliest. This gives an ample time limit to all interested parties to adapt themselves to the new situation.

In the field of agriculture the problems were more complex. The different national regulations should be gradually replaced by common regulations. Within two years after the entering into force of the Treaty the European Commission has to put its proposals before the Council. Until the replacement of the national regulations by common regulations has been completed the development of the exchange of agricultural goods between member states can be affected by means of "long term contracts" which are limited to those products for which a member state has guaranteed an outlet to its national producers and for which other member states have import needs. When a member state is dependent on the import of agricultural raw material for the manufacture of products to be re-exported outside the Community, these long term contracts may not constitute an obstacle for the import of these raw materials from outside the Community. Furthermore the Treaty authorizes each member state to introduce during the transition period and in accordance with certain objective criteria, minimum prices below which the import of agricultural products from other member states are to be either reduced or prohibited.

I fear it will take me too long to elaborate on the elimination of the obstacles to the free movement of labour and capital, the right of citizens 
of one country to establish enterprises in another country or to carry on a profession; on the free movement of servies; the establishment of a common transport policy and the co-ordination of the economic policy of the participating countries.

A very interesting part of the Treaty constitutes the chapter concerning competition between enterprises. Agreements, etc., between enterprises unfavourably affecting trade between member countries and resulting in the prevention, restriction and the distortion of the competition within the common market are prohibited, being incompatible with the Treaty.

On the other hand, exception can be made for agreements, etc., between enterprises contributing to the improvement of the production, the distribution of technical or economic progress. Moreover the enterprises are not allowed to take advantage of their position to impose directly or indirectly unfair purchase and selling prices or other unjust contractual conditions; to restrict the production, sale or technical development to the detriment of the consumers; to apply unequal conditions with regard to trade partners and to conclude agreements with commercial partners, dependent on the acceptance of additional conditions having nothing to do with the subject of these agreements.

Another item of particular interest, not only to the Community but also to third countries is formed by the provisions concerning the common trade policy. During the transition period the governments of the member coun- tries have to co-ordinate their commercial relations with third countries in such a way as to bring about the conditions necessary to the implementation of a common policy in matters of external trade.

The European Commission recommends to the Council of Ministers on the procedure applicable to common action and with a view to the negotiations with third countries on the common tariff.

The European Commission, authorized by the Council, will conduct all trade negotiations with third countries in the near future.

Furthermore I wish to draw your special attention to two institutions that will become very important with regard to the economic expansion of the Community. Firstly the establishment of the European Investment Bank. Its mission is to contribute to the balanced and smooth development of the Conımon Market. For this purpose the Bank shall grant loans and guarantees to facilitate projects for developing less developed regions within the Community, for modernizing or converting enterprises and for creating new economic activities where the financial means of the individual member countries are insufficient to meet the entire expenses involved. The European Investment Bank has already become a reality and has its headquarters in Brussels. Its capital amounts to one milliard units, i.e. approximately one milliard dollars. Admission of a new member country requires an increase of the capital. The total amount of loans 
and guarantees may not exceed $250 \%$ of the capital.

Secondly the Treaty provides for the establishment of a European Social Fund, having as its task to promote within the Community the employment facilities and the geographical and occupational mobility of the workers, thus contributing to the raising of the standard of living.

The European Commission is charged with the supervision of the Fund. On the request of a member state the Fund re-imburses $50 \%$ of the costs necessary for occupational retraining of workers, and of the expenses due to their resettlement necessary to provide them with the new productive employment. Moreover, aids can be granted for the benefit of workers, temporarily wholly or partly out of employment as a result of the conversion of their enterprise to other productions. As you will understand, an adventure of such magnitude as the establishment of the European Economic Community requires a large scale adaptation to new circumstances. One has to take into account that serious difficulties may arise, causing extreme hardships to one or another national economy. Nothing seems more logical than to provide for escape clauses eimed at the prevention of a development that would threaten the very existence of such a member country. The Treaty therefore makes a number of provisions to enable a member country getting into serious troubles to put its affairs in order. I already mentioned the possibility of extending the duration of the first stage of the Common Market with 3 years. Other important escape clauses have to do with the prevention of difficulties which might result from the free movement of capital and a disequilibrium of the balance of payments. I wish to stress, however, that no member country is allowed to make use of these escape clauses without the European Commission having investigated the situation arisen. The European Commission decides whether there is reason to believe that special measures have to be taken. It then submits the necessary proposals, which always have a temporary character, to the Council of Ministers.

I am going to deal now with the reactions of third countries towards the European Economic Community, as they were voiced in the organisation known as GATT, General Agreement on Trade and Tariffs, and the Association of the Overseas Countries and Territories.

Although in principle most third countries have welcomed the birth of this new community as evidence of progressive statesmanship, many of them for fear of the consequences evolving from the implementation of the Treaty to their pattern of trade, still object to certain clauses of the Treaty which might harm their national trading interests. In the meetings of the GATT at Geneva, delegations of these countries have voiced their doubts on the compatability of a number of articles of the Treaty with the provisions of GATT to which the Six have equally subscribed. The Six, however, have referred them to Article XXIV of the GATT which favours the establishment of Customs Unions as having a 
trade creating effect. The GATT, however, stipulates that a customs union should aim at facilitating trade between the countries belonging to such a union, provided that no barriers are raised to the trade of third countries with the member states of that union. Therefore the General Agreement on Trade and Tariffs demands amongst others that the duties and other commercial rules, applying to a customs union, should not, on the whole, be higher or more restrictive than the general incidence of the duties and regulations applicable in the constituent territories prior to the formation of the union.

The Six believe to have complied with this prescription by establishing a general outer tariff, which will progressively replace the existing tariffs of the different member states. They have chosen for the calculation of the new tariff a method which, as a general rule, will be the arithmetical average between the existing tariffs in the different member countries of the European Economic Community. In certain instances the common tariff will even be below this arithmetical average.

For certain groups of products the Treaty provides a maximum duty which the common tariff is not allowed to exceed. The national tariffs will gradually be brought into line with the common tariff by means of three adjustments, to take place successively at the end of the three stages into which the transition period has been divided.

Although the general incidence of the new common tariff seems to be in conformity with the provisions of the GATT Treaty, it must be admitted that the level of the common tariff with regard to certain specific items will be higher than those levied in the few participating countries today. This applies in particular to the Benelux tariff. On the other hand the level of the common tariff will in many cases be lower than the actual tariff in France and Italy.

The future will show whether the consequences certain third countries fear have any real value. Personally I am inclined to believe the opposite.

The general increase in prosperity, as the outcome of the European Economic Community will prove, is beneficial to world trade as a whole. The substance of the Treaty provisions and the flexible nature of the institutional procedure moreover enable the interests of third countries to be taken into full account. Experience has proved that a customs-union tends to have a trade creative effect. A considerable rise in the standard of living of the population of the Community will always lead to a greater purchasing power and cause the development of new needs, the buying of more consumption goods, etc. The standardization of production, the modernization and readaptation of industry, the establishment of new undertakings, the introduction of new production methods demand large investment. All these factors contribute not only to a larger circulation of goods within the boundaries of the Community, but at the same time tend to increase the trade volume with third countries. The Benelux customs union, shortly to be converted into an economic union, undeniably proves the correctness of 
this thesis. Compared with the situation existing before the second world war, there has been a considerable increase in the exchange of trade between the member countries of the Benelux. Although the percentage share of third countries in the Benelux import dropped, the volume of their export trade with the Benelux countries nevertheless showed a favourable development.

The Association of Overseas Territories which constitutes an essential part of the Treaty may be of special interest to you.

The Six arrived at the conclusion that the exclusion of these territories from the Community would mean a breaking off of the economic ties with their mother-countries. This undoubtedly would have the most serious repercussions for these territories on their economic and political development, which to a great extent is dependent on the assistance from, and their relations with, the mother-country. Such a course of action would also be contrary to the solidarity which links the mother-countries to their overseas territories and contrary to the responsibility which they have assumed for their welfare and development.

The fourth chapter of the Treaty is dedicated to this conception. Included are the French Overseas Territories in Africa, America, Australasia, the Pacific and the Antarctic regions. Needless to say that Tunisia and Morocco, having become independent, are not included. As these two countries belong to the French franc zone, the Six will invite the Tunisian and Moroccan
Governments to negotiate a Treaty providing for their association with the Community. An analogous invitation will be sent to the autonomous parts of the Netherlands realm i.e. the Netherlands Antilles and Surinam. Algeria, Réunion, Guadeloupe, Martinique and French Guyana are as integral parts of France, with a few restrictions, considered to be within the boundaries of the Community.

Furthermore the autonomous republic of Togo, Netherlands New Guinea the Belgian Congo, the trust territories French Cameroon, Belgian Ruanda and Urundi and Italian Somaliland form part of the associated territories.

In drawing up the rules which will apply to this association the Six have had regard to no other consideration than the requirements of the economic and industrial development of these territories and of the International Status, which applies to some of them. The Treaty explicitly states that the object of the association is first and foremost the promotion of the economic and social development of these countries and territories, and further the establishment of close economic relations between them and the Community as a whole. The member states have agreed to open their markets to these overseas territories in the same manner as they have done towards each other. In return they will only receive the same commercial treatment as the territory applies to the mother-country concerned.

Although the Six will gradually abolish their tariffs on imports from the overseas territories, the latter only 
gradually have to lower theirs until they reach the level of the tariffs on imports of the mother-country. The Six have furthermore decided to give palpable and concrete evidence of their solidarity with the overseas territories by agreeing to contribute a collective sum of over 220 million pounds to a specially created Development Fund, to be managed by the European Commission. These contributions are complementary to what the mother-countries accomplish themselves. The responsible national authorities will, in agreement with the local authorities or with the local representative bodies of the populations of the territories involved, present the social and economic projects for which financial aid is sought. The size and method of distribution of this aid is laid down in a special convention which contain the modalities of the Association for the first five years. At the end of this five year period a new convention will have to be negotiated.

Personally I firmly believe that from a political point of view the Six arrived at a very sound decision that might have an important influence on the way of life of the populations of these territories.

Regardless of the fact whether it is a good thing or not to accelerate the political emancipation of the peoples still living under European tuition, it cannot be denied that the intelligentsia at the head of political activity in the territories concerned are continuously pressing for independence and that the administering powers as a rule are inclined to meet their demands as far as possible. Since in most cases politi- cal independence is expected to precede economic and social maturity, there will be a constant danger that the backwardness of those countries is blamed to the former colonial rule.

A concerted effort of Western Europe to assist them to develop the economy of their countries will enable them in a way, corresponding with their own culture, to adapt their communities to the demands of world economics. This action seems to be the more essential, since at present the Soviet Union is showing a keen interest in the destiny of Africa, in the chances which the prevailing circumstances in this continent offer the Soviet Union to strike a deadly blow to Western interests and influence, and to have the African peoples espouse the Communist creed. To those who fear that the European Economic Community is creating a privileged position for itself in the markets of the overseas territories, I may point out that the economies of most of these territories are only in an early stage of development, and although their association and the financial aid involved will accelerate the present rhythm of development, for a long time to come, the production and consuming capacity of these countries will not be of sufficient importance to cause any serious disturbance in the pattern of world trade.

The Association of the Overseas Territories constitutes one of the points against which sharp criticism has been levelled in the successive meetings of GATT. 
Many delegations condemned this part of the Treaty as being incompatible with the provisions of GATT. The real reasons were partly economic, partly political. Many third countries are convinced that the consequences of the association will have an unfavourable effect on their pattern of trade.

Although certain countries agree that the establishment of the Community will bring about a larger prosperity to each member country, they believe that only the members and associated members will profit from the extension of the market to the Overseas Territories. $I$ again believe that those who speak in this way overlook the dynamic perspectives of a large expanding market. Apart from their fears concerning the economic disadvantages to their national trading interests which may result from the implementation of the Treaty, the countries which were colonies in the recent past, showed, as could be expected, a deeply rooted suspicion to the association idea. As the somewhat dogmatic convictions those countries cherish do not tally with the belief that the Six within the framework of their planning honestly took full account of the interests of the underdeveloped territories and that the Six really aim at a speedier political, economic and social emancipation of the peoples concerned, those countries are inclined to regard the structure as a renewed effort to keep the other still dependent teritories under colonial control.

I think that an objective study of the opinions prevailing amongst the responsible leaders of the peoples living in these territories, will convince those who entertain the suspicions just mentioned, that the association has most heartily been welcomed and has raised the hope that the realization of the national aims they strive at.will be achieved at a quicker pace. If the findings on my journey to Madagascar in June 1958 do not constitute a solitary case and prove to be representative for the way of thinking in other territories, then I do not doubt the outcome of such a study. In Madagascar at least there is all the evidence that the national leaders place their hopes on the association of their country with the European Common Market and on the prospect of larger financial assistance resulting from the operation of the Development Fund. The Madagascar leaders I met were unanimous in their appreciation of the chances the association offered to their country.

The European commitment, to my opinion, offers a unique chance indeed to convince the leaders in the Overseas Territories that the best interests of their country are served by the association idea embodied in the Treaty. Moreover, as individually the different countries constituting the Community, are scarcely in a position to meet the increasing financial and technical needs of their Overseas Territories, arising from the development plans which are being carried out, the Development Fund will render a significant contribution in this field. On the other hand the free access to the Common Market with its ever increasing consumption power may have an essential influence on the determination of the course the 
Overseas Territories decide to steer. As at the same time nothing will stand in their way to develop their economies and to establish domestic industries, initially protected by custom-barriers, even against European competition, they have, from an economic point of view, all interest in accepting the chances thus offered to them.

The developments in Europe resulting from the implementation of the Treaty.

As the history of the genesis of Benelux and the European Coal and Steel community has repeatedly shown, the first steps to realize the objects of the treaties are the most difficult.

National, industrial, commercial and shipping interests are confronted with an entirely new situation and they sometimes fear the often unknown consequences of the new pattern. It is very human if those enterprises warn their governments and peoples for the expected dire outcome of implementing the provisions of the Treaty agreed upon. On the other hand private enterprise, once the decision has been taken, is inclined to adapt itself to the new situation which has been created and frequently discovers that future prospects are not as dim as has been prophesised.

In this connection I wish to draw your attention to a few examples that might support my point.

Before the Coal and Steel Community came into existence, French steel industrialists feared the consequences of this adventurous scheme. No one could blame them. Being accustomed to a degree of protection for a long time, they could not do otherwise than distrust their capabilities to encounter German competition in particular. As soon as they understood that nothing could change the course of events, they feverishly acted to adapt their industry to the demands of to-morrow. Partly with the help of the French Government they succeeded in attracting large amounts of capital, which were used for the rehabilitation and modernization of the industry.

Before the five years of the transition period of the Treaty had elapsed, the French steel industry was able to compete with the other steel industries within the Community and its attitude towards the Community as such had completely changed.

A better example may be drawn from the conflict between the German Government and the High Authority of the European Coal and Steel community concerning a draft regulation of the latter on the restitution of the purchase tax in case the products falling within the jurisdiction of the Coal and Steel community were exported from one member country to another. Basing itself on the advice of German fiscal and economic experts, the German Government was definitely convinced that the system proposed by the High Authority would mean a deadly blow to the very existence of the German steel industry. As a member of the Netherlands Delegation to the Council of Ministers $I$ happened to take part in the drawn-out discussions on this subject in the Working Committee of the Council. At the decisive meeting of the Council the German Delegation desperately tried again to convince the 
other delegations of the imminent disasters threatening the German steel industry if the proposals of the High Authority became law. A large majority of the Council, however, decided to recommend favourably on the draft of the High Authority. A year afterwards, as nothing had happened and on the contrary the German steel industry prospered as never before, I, having lunch with a few German colleagues and friends and discussing the prosperity of the German steel industry, asked them why they had fought the decision of the High Authority in such an embittered way the year before. They then honestly admitted that they had made an error.

These stories should not induce you to treat lightheartedly objections raised by industrialists, commercial people and technical experts. They only show that, if people are given some time to adapt their business to the new circumstances, their energy and adaptability will in most cases overcome the obstacles that undoubtedly beset their paths. I repeat, if they are given some time. Those who created the European Economic Community have understood this very well. That is why the transition period of the European Economic Community has been fixed at 12 to 15 years. Business and industrial circles will gradually begin to feel the impact of the provisions of the Treaty. They will have sufficient time to readapt their enterprises to the new realities and $I$ have no doubt that those enterprises, not working on the very brink of existence, will notwithstanding the protection granted to them in the past, respond favourably to the challenge the Treaty has called to them.

Notwithstanding the institutional set-up of the Community and the authority vested in the European Commission and the Council of Ministers, the good intentions of those responsible for the implementation of the Treaty will be of major importance to the realization of the Community. The pressure exercised by the European Assembly, the national parliaments and private interests of the governments, will also favour the realization of complete European integration within the time-table set by the Treaty. Once change begins, it will be carried forward more and more rapidly by its own momentum. So for instance, as their expansion programs need longterm planning and require certainty with regard to future developments, industrial concerns and large enterprises will after all exert pressure on a speedy and complete fulfilment of the Treaty objects.

As the experience with the Coal and Steel Parliament has already proved, the European Assembly, consisting of members appointed by the national parliaments, will exert a large direct and indirect influence on the activities of the European Commission responsible to the European parliament and on the Council of Ministers.

Although the Council of Ministers is not responsible to the European Assembly, the Ministers, individually, will be confronted in their national parliaments by the criticism levelled by parliamentary representatives, who possess the dual capacity of National Member of 
Parliament and member of the European Assembly. As the National Parliaments used to nominate their prominent members to the European Assemblies, the influenc of their views should not be underestimated. Like the High Authority and the other institutions of the European Coal and Steel Community, the distinguished persons invited to take their place in the institutions of the European Economic Community are bound to become imbued with a European notion and outlook almost from the beginning. The officialdom of the institutions of the Community, generally being drawn from the most able elements of the intellectual classes of the member countries, will become thoroughly European in outlook and their activities will have a large influence on the implementation of the Treaty. It is clear that all these factors will contribute to the cementation of the European unity.

In the economic field important changes are to be expected. Especially the large industrial concerns are already feverishly making their preparations to meet the coming events, since the provisions of the Treaty have opened the way to a large expansion of their activities. Specialization and automatization, with the large market in view, are now feasible, so will standardization of production, the construction of a smaller number of types but massproduced; the concentration of industries, particularly of those producing mass-goods, come within reach of practical possibility.

In anticipation of the coming developments a number of American industrialists, convinced of the new prospects offered by the Community, have already set up subsidiaries of their enterprises within the boundaries of the Community in order to profit from the large market which is nascent. Western European industrialists are already examining closely what changes in management, production methods, etc., have to be made in order to intercept the changes or overcome the difficulties they believe to be imminent.

With a view to the rapid expansion of Europe's economy expected to be further stimulated by the coming Community, the Municipal Council of Rotterdam, the world's second port today, voted the first credits of 6.8 million pounds for the construction of an entire new port area, the Eurogate. Work has already started and the new harbour works will be completed by 1965 at an estimated cost to the city of more than 17 million pounds. It will have docks and dry docks for 100,000 ton ships, a steel mill, oil refineries and a coal processing plant. There will also be storage areas for ore, coal, petroleum and other raw materials. Although I have no specific other information at my disposal, I am convinced that everywhere in Western Europe there is a lot of activity and planning going on with regard to the events that are about to occur.

I, as a citizen of this Community, am proud of the progressive realization of a dream and am thankful of being allowed to witness the beginning of the creation of a new Europe, which, as I feverntly hope, will shortly become again a centre 
of political, economic, technical, social and cultural progress enabling it to resume its historical task as a beacon of Western civilization to mankind.

S. MEIJER.

Ambassade der Nederlanden. 